Abstracta Iranica Abstracta Iranica

Revue bibliographique pour le domaine irano-aryen

Volume 24 | 2003

Comptes rendus des publications de 2001

\title{
« Mamluk Legitimacy and Mongols: The Reigns of Baybars and Qalāwūn ». Mamluk Studies Review, 5, 2001, pp. 91-118.
}

\section{Denise Aigle}

\section{(2) OpenEdition}

Journals

Édition électronique

URL : http://journals.openedition.org/abstractairanica/34388

DOI : 10.4000/abstractairanica.34388

ISSN : 1961-960X

Éditeur :

CNRS (UMR 7528 Mondes iraniens et indiens), Éditions de l'IFRI

\section{Édition imprimée}

Date de publication : 15 mai 2003

ISSN : 0240-8910

Référence électronique

Denise Aigle, « " Mamluk Legitimacy and Mongols: The Reigns of Baybars and Qalāwūn ». Mamluk Studies Review, 5, 2001, pp. 91-118. », Abstracta Iranica [En ligne], Volume 24 | 2003, document 108, mis en ligne le 05 janvier 2010, consulté le 25 septembre 2020. URL : http://journals.openedition.org/ abstractairanica/34388; DOI : https://doi.org/10.4000/abstractairanica.34388

Ce document a été généré automatiquement le 25 septembre 2020.

Tous droits réservés 
«Mamluk Legitimacy and Mongols: The Reigns of Baybars and Qalāwūn ». Mamluk Studies Review, 5, 2001, pp. 91-118.

Denise Aigle 
1 L'objectif de l'auteur dans cet article, appuyé sur un large éventail de sources arabes, est d'analyser pourquoi les Mamelouks, et Baybars en particulier, ont fondé leur légitimité sur l'islam dans leurs relations avec deux khanats mongols, les khans de la Horde d'or et les Ilkhans d'Iran. Les attaques mongoles de la Syrie ont donné lieu à une véritable « guerre idéologique » dans laquelle la religion joua le rôle principal. L'auteur analyse le récit des ambassades et les correspondances échangées entre ces trois pouvoirs, dont on ne possède pas les originaux mais qui ont été transmises dans les sources narratives.

2 Redoutant une alliance entre les Mongols d'Iran et l'Occident, les Mamelouks ont cherché l'appui de la Horde d'or, dont le souverain, Berke Khan, était converti à l'islam. Le sultan Baybars, arrivé au pouvoir après avoir été l'instigateur de deux régicides était, de surcroît, marqué par les stigmates de la servilité face aux gengiskhanides de sang impérial : il n'avait d'autre choix pour se donner une légitimité que de s'appuyer sur l'islam. L'auteur montre comment Baybars, pour se poser en égal face à Berke Khan, a joué sur la fibre islamique en ordonnant, par exemple, au calife qu'il avait restauré au Caire après la chute de Bagdad, de prononcer la bay'a juste au moment où une délégation mongole en provenance des territoires de Berke Khan se trouvait en Égypte.

Cet article n'apporte pas de thèse nouvelle sur les relations entre Mamelouks et Ilkhans, mais son auteur met en perspective les travaux antérieurs sur la question, notamment ceux de Reuven Amitai-Preiss (en particulier Mongols and Mamluks. The Mamluk-Īlkhānid War, 1260-1281, Cambridge, 1995), tout en utilisant des sources complémentaires.

\title{
INDEX
}

Thèmes : 4.1. Histoire médiévale

\author{
AUTEURS \\ DENISE AIGLE \\ IFEAD - Damas
}

